
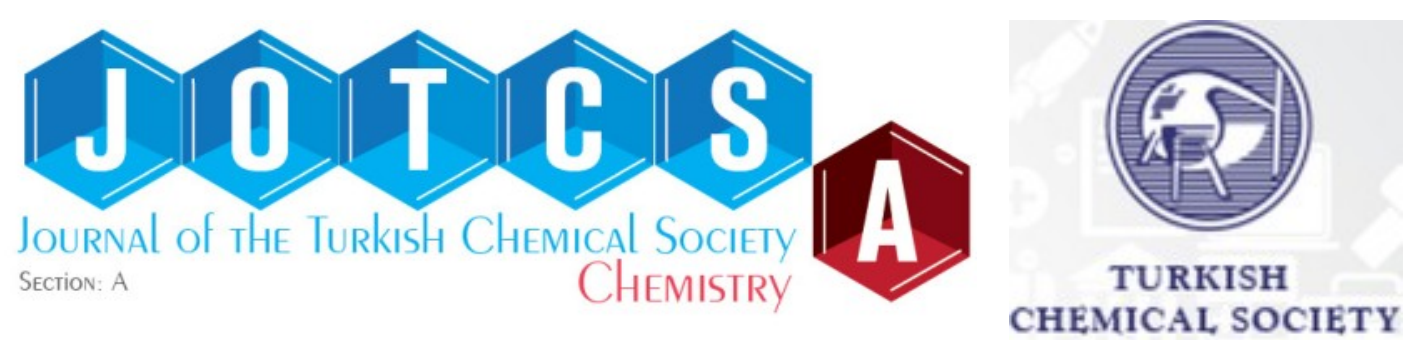

\title{
Oxovanadium(IV) Template Derived from Benzophenone S-allyl Thiosemicarbazone: Synthesis, Crystal Structure, Antioxidant Activity and Electrochemistry
}

\author{
Berat İlhan-Ceylan*
}

Istanbul University-Cerrahpasa, Engineering Faculty, Department of Chemistry, Inorganic Chemistry Division, 34320, Avcilar, Istanbul, Turkey.

\begin{abstract}
The oxovanadium(IV) template was formed with the reaction between vanadyl sulfate pentahydrate, 2-hydroxybenzophenone-S-allylthiosemicarbazone, and 3-methoxysalicylaldehyde. The synthesized template complex, along with the starting ligand, was subjected to UV-Vis, FTIR, ESI-mass, and magnetic measurement. The square pyramidal structure was proven with the single-crystal $X$-ray diffraction method. Stronger crystals were formed with $\pi-\pi$ interactions, which was also supported by the corresponding peak in the mass spectrum. Electrochemical measurements was performed using a conventional three-electrode cell with cyclic voltammetry (CV) method. CV results show that complex 2 gives one-electron reduction $\left(\mathrm{V}^{\mathrm{IV}} \mathrm{O}-\mathrm{V}^{\mathrm{III}} \mathrm{O}\right)$ couple and one-electron oxidation $\left(\mathrm{V}^{\mathrm{IV} O}-\mathrm{V}^{\mathrm{V}} \mathrm{O}\right)$ couple at the vanadium center. The total antioxidant capacity of the template compound and the starting ligand was performed by the CUPRAC method, yielding that the complex was more potent than the control compound, ascorbic acid.
\end{abstract}

Keywords: Thiosemicarbazone, oxovanadium(IV), antioxidant capability, electrochemistry, X-ray crystallography.

Submitted: April 07, 2021. Accepted: April 23, 2021.

Cite this: İlhan-Ceylan B. Oxovanadium(IV) Template Derived from Benzophenone S-allyl thiosemicarbazone: Synthesis, Crystal Structure, Antioxidant Activity and Electrochemistry. JOTCSA. $2021 ; 8(2): 593-608$.

DOI: https://doi.org/10.18596/jotcsa.911318.

*Corresponding author. E-mail: beril@istanbul.edu.tr.

\section{INTRODUCTION}

Complexes of vanadium have antimicrobial, antibacterial, antitumoral, and catalytic activity and insulin-enhancing effects. Vanadium has the potential of displaying oxidation states of III, IV, and $\mathrm{V}$, and readily forming $\mathrm{V}-\mathrm{O}$ bonds and binding nitrogen and sulfur. Nitrogenase and haloperoxidases are important vanadiumcontaining enzymes (1-3).

Vanadium salts act as insulin-like behavior in the cells and in diabetic animals, and this has been known since the 80s. Frequently, diabetic patients have abnormal levels of glucose and lipids in the blood, and insulin treatment can normalize this abnormality. It has been shown that, in animal model systems and human beings, treatment with vanadium complexes and vanadium salts could alleviate the symptoms of diabetes $(1,4,5)$. In vivo insulin-like activity $(6,7)$ and in vitro insulinmimetic activities of oxovanadium(IV) complexes with thiosemicarbazones are also reported $(8,9)$.

Thiosemicarbazones and related metal complexes display important biological and therapeutic properties, such as catalytic applications (10-12), sensors (13), antioxidant $(14,15)$, cytotoxic (16, 
17), antidiabetic (18), antimalarial (19), antiviral $(20,21)$, antimicrobial $(17,22)$, antifungal (23, $24)$, antibacterial $(25,26)$, anticancer (27), and antitumoral $(16,28,29)$ activities.

In this work, an oxovanadium(IV) thiosemicarbazone (2) template structure was prepared with 2-hydroxybenzophenone Sallylthiosemicarbazone (1) and 3methoxysalicylaldehyde. The single crystals of compound 2 were obtained, and cyclic voltammetry $(\mathrm{CV})$, thermogravimetric analysis (TGA), and antioxidant efficiency (with the CUPRAC method) were studied. It was found that compound $\mathbf{2}$ was more active than compound $\mathbf{1}$. Also, the crystalline structure revealed that there were interactions of $\pi-\pi$ and $C-\pi$ nature in the $X-$ ray crystal determination.

\section{EXPERIMENTAL}

\section{General Remarks}

All chemicals were of reagent grade and they were used as received. For elemental analyses, a Thermo Finnigan Flash EA 1112 device and for molar conductivity measurements, a Therma conductivity meter was employed. Fourier transform infrared spectral measurements were performed with an Agilent Cary 630 FT-attenuated total reflectance (ATR) spectrometer between 4000 and $600 \mathrm{~cm}^{-1}$. For antioxidant capacity measurements, a Shimadzu brand UV-2600 spectrophotometer working in the ultravioletvisible range was used, and a matched pair of quartz cuvettes with $10 \mathrm{~mm}$ path length were equipped. All determinations were done at room temperature.

For X-ray crystallography, data collection was carried out with a Bruker brand, APEX2 CCD diffractometer and data were reduced with Bruker SAINT (30). Solving and refinement of the structure were performed with SHELXT 2018/2 and SHELXL-2018/3 (31, 32). Direct methods were used for the solvation of the structure, which was refined on $F^{2}$ using all the reflections.

\section{Synthesis}

2-hydroxybenzophenone-S-allylthiosemicarbazone (1) was synthesized by applying slight modifications to the literature procedure. Briefly, the compound was stirred in ethanol to get rid of sticky substances, and then $5 \%$ sodium hydrogen carbonate solution was added and therefore the synthetic yield was increased $(14,33)$.

Triethyl orthoformate $(1.0 \mathrm{~mL})$ and vanadyl sulfate pentahydrate $(1.0 \mathrm{mmol})$ in $5.0 \mathrm{~mL}$ of ethanol were reacted overnight at room temperature. The solution was treated with a mixture of compound $\mathbf{1}$
(1.0 $\mathrm{mmol})$ and 3-methoxysalicylaldehyde (1.0 $\mathrm{mmol}$ ) in ethanol $(5.0 \mathrm{~mL})$. For a few days, the mixture was kept at room temperature, and the black-colored product obtained (2) was washed with cold ethanol. The template complex yielded the following experimental data which were described below.

Oxovanadium(IV) complex (2): Black, m.p. 284.8-285.3 ${ }^{\circ} \mathrm{C}$, yield $12 \%$. Molar Conductivity (DMSO, $\Omega^{-1} \mathrm{~cm}^{2} \mathrm{~mol}^{-1}$ ): 8.2. Anal. Calc. for $\mathrm{C}_{25} \mathrm{H}_{23} \mathrm{~N}_{3} \mathrm{O}_{5} \mathrm{SV}(528.47 \mathrm{~g} / \mathrm{mol}): \mathrm{C}, 56.82 ; \mathrm{H}, 4.39$; $\mathrm{N}, 7.95 ; \mathrm{S}, 6.07$. Found: $\mathrm{C}, 56.43 ; \mathrm{H}, 4.55 ; \mathrm{N}$, $7.44 ; \mathrm{S}, 5.79 \%$. UV-Vis $\left(\mathrm{CHCl}_{3}\right)\left[\lambda_{\max }(\mathrm{nm}), \log \varepsilon\right.$ $\left.\left(\mathrm{dm}^{3} \mathrm{~cm}^{-1} \mathrm{~mol}^{-1}\right)\right]$ : 239(5.03) 258(4.99) 333(4.83) 359(4.77) 434(4.52). IR $\left(\mathrm{cm}^{-1}\right): \mathrm{v}\left(\mathrm{C}=\mathrm{N}^{1}\right)$ 1608, 1601; $\mathrm{v}\left(\mathrm{C}=\mathrm{N}^{2}\right)$ 1574; $\mathrm{v}\left(\mathrm{N}^{4}=\mathrm{C}\right)$ 1519; $\mathrm{v}\left(\mathrm{C}_{\mathrm{ar}}-\mathrm{O}\right)$ 1149, 1104; $v(\mathrm{~N}-\mathrm{N})$ 1025; $\mathrm{v}(\mathrm{V}=\mathrm{O})$ 966, $\mathrm{v}(\mathrm{C}-\mathrm{S})$ 746. MS m/z (\%): $\left[\left(\mathrm{M}-\mathrm{H}_{2} \mathrm{O}\right)+\mathrm{Na}\right]^{+} 533.1$ (22.91), $\left[\left(2 \mathrm{M}+\mathrm{H}_{2} \mathrm{O}\right)+\mathrm{Na}\right]^{+} 1042.8(100)$.

\section{Cyclic Voltammetry}

A conventional three-electrode cell system was employed for the electrochemical measurements. A glassy carbon electrode (GCE) having a diameter of $3.0 \mathrm{~mm}$ was used as the working electrode. A $\mathrm{Ag} / \mathrm{AgCl}$ reference electrode and a platinum wire counter electrode were also used to complete the circuit. The working electrode, before each run, was polished with an alumina slurry, obtained from Buehler Micropolish, on a Buehler-102 mm polishing pad and rinsed with distilled water.

The electrochemical measurements were performed for compound (2) at $1.0 \times 10^{-3} \mathrm{M}$ concentration in electrochemically pure dimethyl sulfoxide, along with, as the supporting electrolyte, $0.1 \mathrm{M} \mathrm{Bu} \mathrm{Bu}_{4}^{+} \mathrm{ClO}_{4}^{-}$(TBAP) under nitrogen atmosphere.

\section{CUPRAC study}

To study the total antioxidant capacity of the compounds, CUPRAC (CUPric Reducing Antioxidant Capacity) was employed (34). Under identical conditions, calculations of the molar absorption coefficients were performed for every compound. By taking the selected compound's molar absorptivity as a fraction of trolox, TEAC (troloxequivalent antioxidant capacity) values were computed. Into a test tube were placed, in this very order, copper(II) chloride dihydrate $(1.0 \mathrm{~mL}$, $10 \mathrm{mM}$ ), neocuproine ( $\mathrm{Nc} ; 1.0 \mathrm{~mL}, 7.5 \mathrm{mM}), \mathrm{pH}=$ 7 ammonium acetate buffer $(1.0 \mathrm{~mL}, 1.0 \mathrm{M})$, antioxidant sample solution $(x \mathrm{~mL})$, and distilled water $(1.1-x \mathrm{~mL})$. The total volume was $4.1 \mathrm{~mL}$, and after an incubation period of half an hour, the absorbance at $450 \mathrm{~nm}$ was recorded against a blank, which does not include the reagents. The computation of TEAC coefficients was performed with the following equation: 


$$
T E A C \text { coefficient }=\frac{\text { molar absorptivity of the compound }}{\text { molar absorptivity of trolox }\left(1.67 \times 10^{4} \mathrm{~L} \mathrm{~mol}^{-1} \mathrm{~cm}^{-1}\right)}
$$

\section{RESULT AND DISCUSSION}

\section{Synthesis}

The yield of synthesis was poor; it was because the complexation reaction was conducted at room temperature, and suitable single crystals were attempted to isolate, in a dark environment with no stirring at all, for 3-4 days. Otherwise, X-raysuitable crystals could not be obtained. Template condensations require the presence of a metal ion; in our case, the oxovanadium(IV) ion was used to conduct the complexation and provide the Schiff base condensation of the $\mathrm{N}^{4}$ thioamide moiety, which is unable to react without a template condensation. The template complexes, as well as the reagents, are stable in the air, which increases the application of them.

\section{Molar Conductivity}

Compound (2) had a molar conductivity of $8.2 \Omega^{-1}$ $\mathrm{cm}^{2} \mathrm{~mol}^{-1}$ in a $10^{-3} \mathrm{M}$ DMSO solution at room temperature. This value is indicative of the nonelectrolytic nature of the complex; according to references, this means the absence of anions (3537).

\section{Crystallographic Studies}

The oxovanadium(IV) complex (2) crystallized in the triclinic space group $\mathrm{P}-1$ (2) with $\mathrm{Z}=2$. Compound 2's several properties are displayed in Table 1 (bond lengths), Table 2 (bond angles) and Table 3 (torsion angles) and Tables S1a (atomic coordinates) and S2a (hydrogen bonds). Figures 1 , 2 , and 3 summarize structural refinement parameters and principal crystalline data.

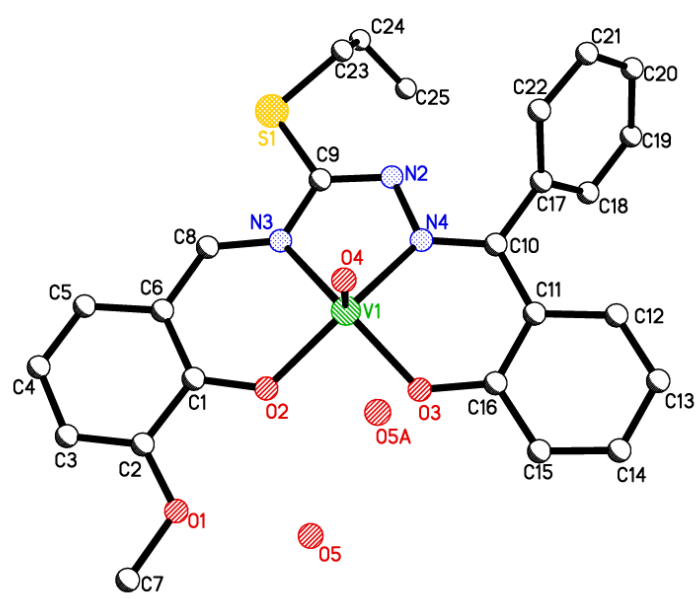

Figure 1: Perspective view of oxovanadium(IV) complex (2) with atom numbering.

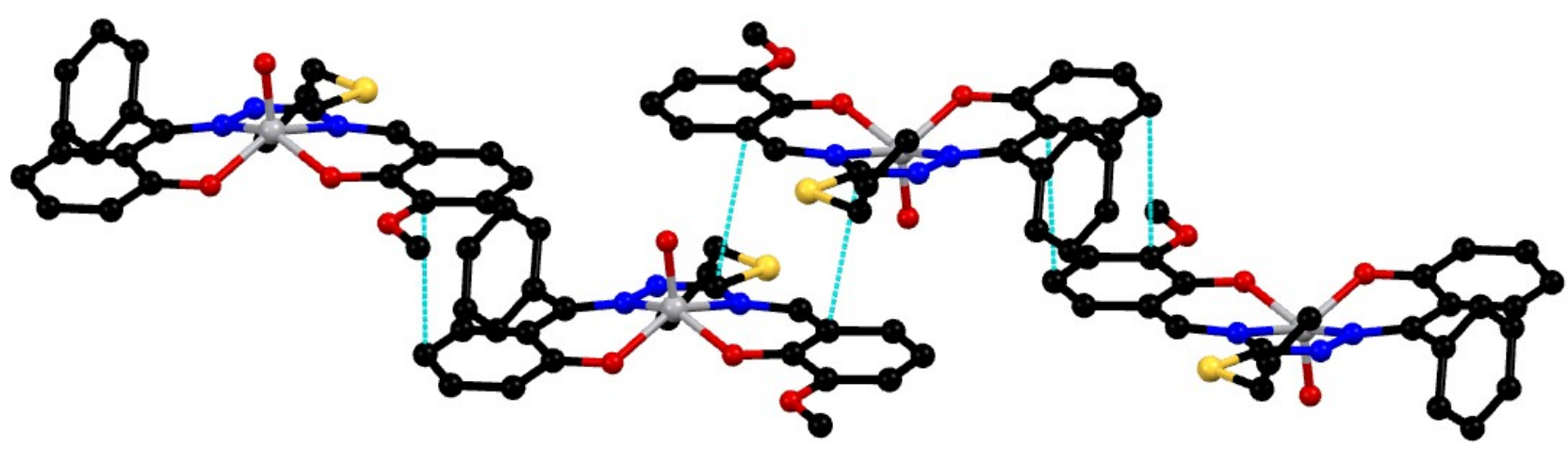

Figure 2: $\pi-\pi$ stacking interactions for the oxovanadium(IV) complex (2). 
Table 1: Crystalline data and structure refinement for the oxovanadium(IV) complex (2).

\begin{tabular}{|ll}
\hline Identification code & Oxovanadium(IV) complex (2) \\
Empirical formula & $\mathrm{C}_{25} \mathrm{H}_{25} \mathrm{~N}_{3} \mathrm{O}_{5} \mathrm{~S} \mathrm{~V}$ \\
Formula weight & 530.45 \\
Temperature & $293(2) \mathrm{K}$ \\
Wavelength & $0.71073 \AA$ \\
Crystal system & Triclinic \\
Space group & $\mathrm{P}-1$ \\
Unit cell dimensions & $\mathrm{a}=9.5801(10) \AA, \alpha=100.737(10)^{\circ}$ \\
& $\mathrm{b}=11.9561(14) \AA, \beta=100.758(9)^{\circ}$ \\
Volume & $\mathrm{C}=12.1053(14) \AA, \gamma=111.107(10)^{\circ}$ \\
Z & $1221.2(3) \AA^{3}$ \\
Density (calculated) & 2 \\
Absorption coefficient & $1.443 \mathrm{mg} / \mathrm{m}^{3}$ \\
F(000) & $0.536 \mathrm{~mm} \mathrm{~m}^{-1}$ \\
Crystal size & 546 \\
Theta range for data collection & $0.16 \times 0.11 \times 0.08 \mathrm{~mm} \mathrm{~m}^{3}$ \\
Index ranges & 3.339 to $27.779^{\circ}$. \\
Reflections collected & $-8<=\mathrm{h}<=11,-15<=\mathrm{k}<=13,-13<=\mathrm{l}<=15$ \\
Independent reflections & 7210 \\
Completeness to theta $=25.242^{\circ}$ & $4774[\mathrm{R}(\mathrm{int})=0.0344]$ \\
Max. and min. transmission & 0.7457 and 0.5092 \\
Refinement method & $\mathrm{Full}-\mathrm{matrix}$ least-squares on $\mathrm{F}^{2}$ \\
Data / restraints / parameters & $4774 / 1 / 328$ \\
Goodness-of-fit on $\mathrm{F}^{2}$ & 1.024 \\
Final R indices [I $>2$ sigma(I)] & $\mathrm{R} 1=0.0785, \mathrm{wR} 2=0.1929$ \\
R indices (all data) & $\mathrm{R} 1=0.1335, \mathrm{wR} 2=0.2305$ \\
Extinction coefficient & $\mathrm{n} / \mathrm{a}$ \\
Largest diff. peak and hole & 0.722 and $-0.657 \mathrm{e} . \AA^{-3}$ \\
\hline & \\
\hline
\end{tabular}

Table 2: Selected bond distances $[\AA]$ and angles $\left[{ }^{\circ}\right]$ for oxovanadium(IV) complex (2).

\begin{tabular}{|c|c|c|c|}
\hline Atoms & Distances $[\AA]$ & Atoms & Angles $\left[{ }^{\circ}\right]$ \\
\hline $\mathrm{V}(1)-\mathrm{O}(4)$ & $1.603(4)$ & $\mathrm{O}(4)-\mathrm{V}(1)-\mathrm{O}(3)$ & $111.6(2)$ \\
\hline$V(1)-O(3)$ & $1.894(4)$ & $\mathrm{O}(4)-\mathrm{V}(1)-\mathrm{O}(2)$ & $108.35(17)$ \\
\hline$V(1)-O(2)$ & $1.947(3)$ & $\mathrm{O}(3)-\mathrm{V}(1)-\mathrm{O}(2)$ & $87.82(15)$ \\
\hline $\mathrm{V}(1)-\mathrm{N}(3)$ & $2.036(5)$ & $\mathrm{O}(4)-\mathrm{V}(1)-\mathrm{N}(3)$ & 108.07(19) \\
\hline$V(1)-N(4)$ & $2.043(4)$ & $\mathrm{O}(3)-\mathrm{V}(1)-\mathrm{N}(3)$ & $139.47(17)$ \\
\hline$S(1)-C(9)$ & $1.758(6)$ & $\mathrm{O}(2)-\mathrm{V}(1)-\mathrm{N}(3)$ & $87.40(16)$ \\
\hline$S(1)-C(23)$ & $1.787(7)$ & $O(4)-V(1)-N(4)$ & $103.90(18)$ \\
\hline $\mathrm{O}(1)-\mathrm{C}(2)$ & $1.343(7)$ & $O(3)-V(1)-N(4)$ & $86.67(16)$ \\
\hline $\mathrm{O}(1)-\mathrm{C}(7)$ & $1.423(6)$ & $\mathrm{O}(2)-\mathrm{V}(1)-\mathrm{N}(4)$ & $147.02(18)$ \\
\hline $\mathrm{O}(2)-\mathrm{C}(1)$ & $1.306(6)$ & $N(3)-V(1)-N(4)$ & $76.12(17)$ \\
\hline $\mathrm{O}(3)-\mathrm{C}(16)$ & $1.319(6)$ & $\mathrm{C}(1)-\mathrm{O}(2)-\mathrm{V}(1)$ & $128.9(3)$ \\
\hline$N(2)-C(9)$ & $1.295(7)$ & $C(16)-O(3)-V(1)$ & $127.1(3)$ \\
\hline$N(2)-N(4)$ & $1.405(6)$ & $C(8)-N(3)-V(1)$ & $126.1(4)$ \\
\hline$N(3)-C(8)$ & $1.326(6)$ & $C(9)-N(3)-V(1)$ & $112.9(4)$ \\
\hline$N(3)-C(9)$ & $1.410(6)$ & $C(10)-N(4)-V(1)$ & $128.0(4)$ \\
\hline$N(4)-C(10)$ & $1.317(6)$ & $C(10)-N(4)-N(2)$ & $114.5(4)$ \\
\hline
\end{tabular}

Symmetry transformations used to generate equivalent atoms. 
Table 3: Hydrogen bonds for oxovanadium(IV) complex (2) [ $\AA$ and $\left.{ }^{\circ}\right]$.

\begin{tabular}{lllll}
\hline $\mathrm{D}-\mathrm{H} \ldots \mathrm{A}$ & $\mathrm{d}(\mathrm{D}-\mathrm{H})$ & $\mathrm{d}(\mathrm{H} \ldots \mathrm{A})$ & $\mathrm{d}(\mathrm{D} \ldots \mathrm{A})$ & $<(\mathrm{DHA})$ \\
\hline $\mathrm{C}(4)-\mathrm{H}(4) \ldots \mathrm{O}(4) \# 1$ & 0.93 & 2.65 & $3.483(7)$ & 149.3 \\
$\mathrm{C}(8)-\mathrm{H}(8) \ldots \mathrm{O}(4) \# 2$ & 0.93 & 2.61 & $3.371(7)$ & 139.4 \\
$\mathrm{C}(18)-\mathrm{H}(18) \ldots \mathrm{O}(3) \# 3$ & 0.93 & 2.43 & $3.295(7)$ & 153.8 \\
$\mathrm{O}(5 \wedge \mathrm{a})-\mathrm{H}\left(5 A^{\wedge} \mathrm{a}\right) \ldots \mathrm{O}(1)$ & 0.85 & 2.41 & $2.988(14)$ & 126.2 \\
$\mathrm{O}(5 \wedge \mathrm{a})-\mathrm{H}\left(5 A^{\wedge} \mathrm{a}\right) \ldots \mathrm{O}(2)$ & 0.85 & 2.58 & $3.354(13)$ & 152.8 \\
$\mathrm{O}\left(5 A^{\wedge} \mathrm{b}\right)-\mathrm{H}(5 \mathrm{AA} \wedge \mathrm{b}) \ldots \mathrm{O}(4)$ & 0.85 & 2.39 & $2.991(13)$ & 128.3 \\
\hline
\end{tabular}

Symmetry transformations used to generate equivalent atoms:

$$
\# 1 \mathrm{x}-1, y, \mathrm{z} \quad \# 2-\mathrm{x}+1,-\mathrm{y},-\mathrm{z}+1 \quad \# 3-\mathrm{x}+2,-\mathrm{y}+1,-\mathrm{z}+1
$$

Vanadium template complex forms two six- and one five-membered rings. In the six-membered rings, the bond angles are very close with $\mathrm{O}(3)$ $\mathrm{V}(1)-\mathrm{N}(4)$ being $86.67 \AA$ while $\mathrm{O}(2)-\mathrm{V}(1)-\mathrm{N}(3)$ is 87.40 $\AA$. The five-membered ring has a $N(3)-V(1)-$ $\mathrm{N}(4)$ angle of $76.12^{\circ}$. When dealing with bond distances, the shortest bond was $1.603 \AA$ for $V(1)$ $\mathrm{O}(4)$ while the longest bond was $2.043 \AA$ for $V(1)$ $\mathrm{N}(4)$. Experimental results show that vanadiumoxygen bonds are shorter than vanadium-nitrogen bonds $(38,39)$. The previous publication could be accessed for detailed crystalline data and related comments about S-allyl thiosemicarbazone (1) (14).
A disordered water molecule (O5 and $\mathrm{O} 5 \mathrm{~A}$ ) is present in the asymmetric unit and this was computed over two positional site occupancies, 0.576 and 0.424 , respectively. Moreover, the allyl group C23-C24-C25 is quite a lot disordered and the modeling of this disorder did not give better refinement values; therefore it was left as it is.

The stacking-type $\pi-\pi$ interactions forge a link for compound $\mathbf{2}$. In these interactions, complexes' aromatic rings are linked on adjacent parallel planes containing the other complex's ligand portion. Figure 2 shows the $\pi-\pi$ stacking for compound $\mathbf{2}$. It is concluded that the $\pi-\pi$ stacking works in the stabilization of the structure (40).

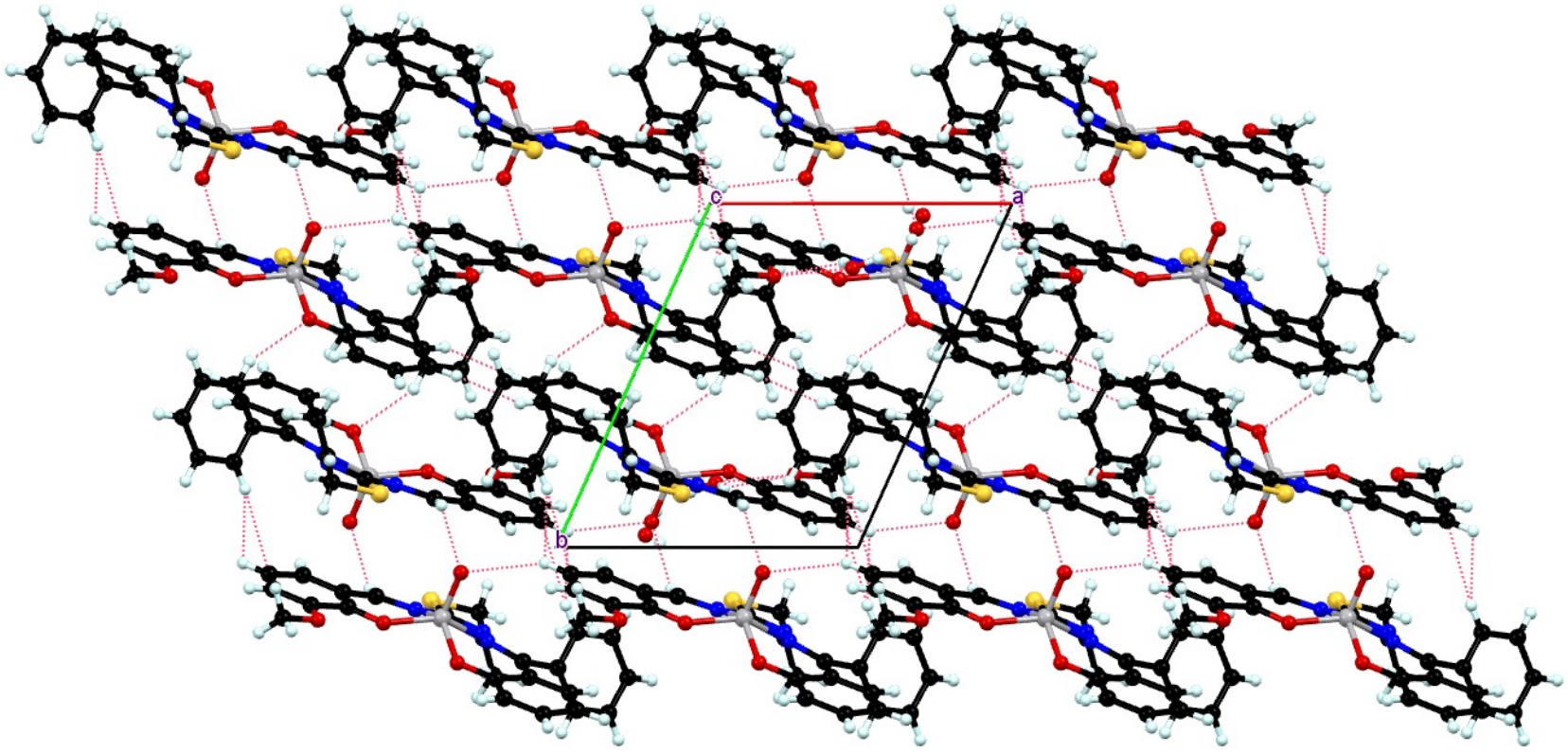

Figure 3: The $\mathrm{CH} \cdots \mathrm{O}$ hydrogen bonds forming a 2D hydrogen bond network for (2).

Addison tau parameter (39) gives an indication of the closeness of the structure, either to the ideal square pyramidal or to the trigonal bipyramidal geometry. Equation (1) was computed with $\mathrm{O}(2)$ $\mathrm{V}(1)-\mathrm{N}(4)$ as $\beta\left(147.02^{\circ}\right)$ and $\mathrm{O}(3)-\mathrm{V}(1)-\mathrm{N}(3)$ as a $\left(139.47^{\circ}\right)$ (Table 3 ) for compound (2) to find the Addison tau parameter. Tau parameter being equal to zero leads to the ideal square pyramidal geometry, and the result is very close to zero ( $\mathrm{T}$ $=0.13$ ) (41).

$$
\tau=\frac{(\beta-\alpha)}{60}
$$

\section{Electrochemistry}

Cyclic voltammetry was performed, for getting information about the electrochemical behavior of the compound (2), within -1.4 to $+1.4 \mathrm{~V}$ versus 
$\mathrm{Ag} / \mathrm{AgCl}$ reference electrode in TBAP/DMSO electrolyte system (Figure 4). In DMSO, complexes containing different metal ions displayed excellent behaviors of voltammetry, with redox processes of the metal and ligand centers. To characterize all the electrode processes, peak-to-peak separation $\left(\Delta_{\mathrm{ep}}\right)$ and the ratio of anodic to cathodic peak currents $\left(I_{p a} / I_{p c}\right.$ ) were used. Table 4 lists the electrochemical parameters from the $\mathrm{CV}$ at $0.1 \mathrm{~V} \mathrm{~s}$ 1 scan rate.

Cyclic voltammogram of the complex (2) in electrochemically pure DMSO containing TBAP as electrolyte demonstrated a wave at $0.56 \mathrm{~V}$ (reversible) and another wave at $-0.77 \mathrm{~V}$ (irreversible) vs. $\mathrm{Ag} / \mathrm{AgCl}$ reference electrode (43).

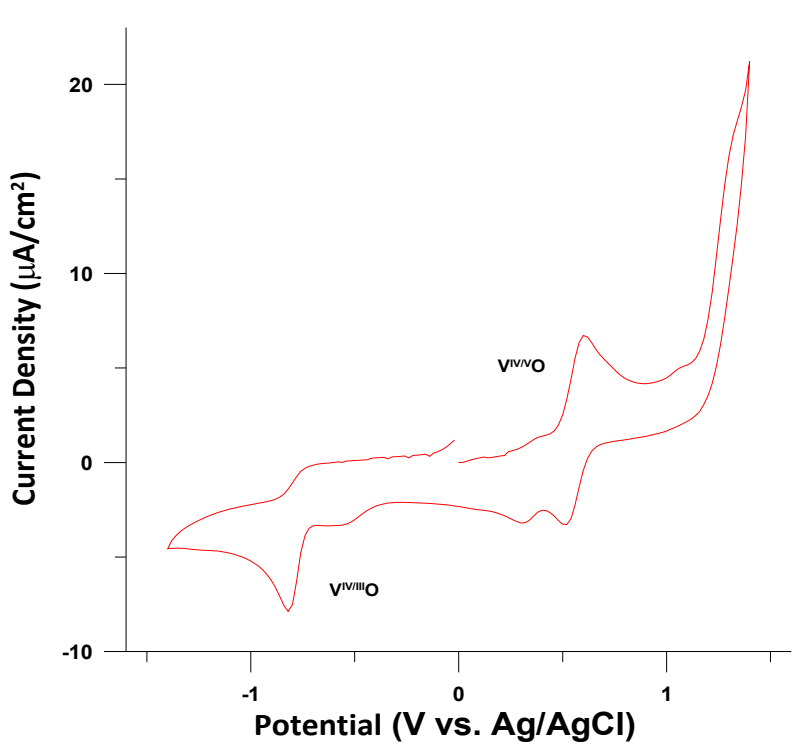

The cathodic redox couple is assignable to the $\mathrm{V}^{\mathrm{IV}} \mathrm{O}$ to $\mathrm{V}^{\mathrm{V}} \mathrm{O}$ oxidation process at a scan rate of 100 $\mathrm{mVs}^{-1}$. $\Delta \mathrm{Ep}$ value of this redox couple was $80 \mathrm{mV}$ and the $i_{p a} / i_{p c}$ value was almost unity, which is indicative of the reversible character of this process. An irreversible redox couple $\left(\Delta \mathrm{E}_{\mathrm{p}}, 100 \mathrm{mV}\right.$ and $\mathrm{I}_{\mathrm{pa}} / \mathrm{I}_{\mathrm{pc}}, 0.20$ ) was attributable to the reduction of $\mathrm{V}^{\mathrm{IV} O}$ to $\mathrm{VIIIO}$ at $-0.77 \mathrm{~V}$. Although the $\Delta \mathrm{Ep}$ value of the reduction couple seemed to be a quasireversible redox process, the tiny $\mathrm{I}_{\mathrm{pa}} / \mathrm{I}_{\mathrm{pc}}$ ratio $(0.2)$ explains the irreversibility (44). There is a shoulder at $-0.65 \mathrm{~V}$ and this value was mentioned of in a previous report (38), which is possibly indicative of an electrode/electrolyte interface adsorption process $(45,46)$.

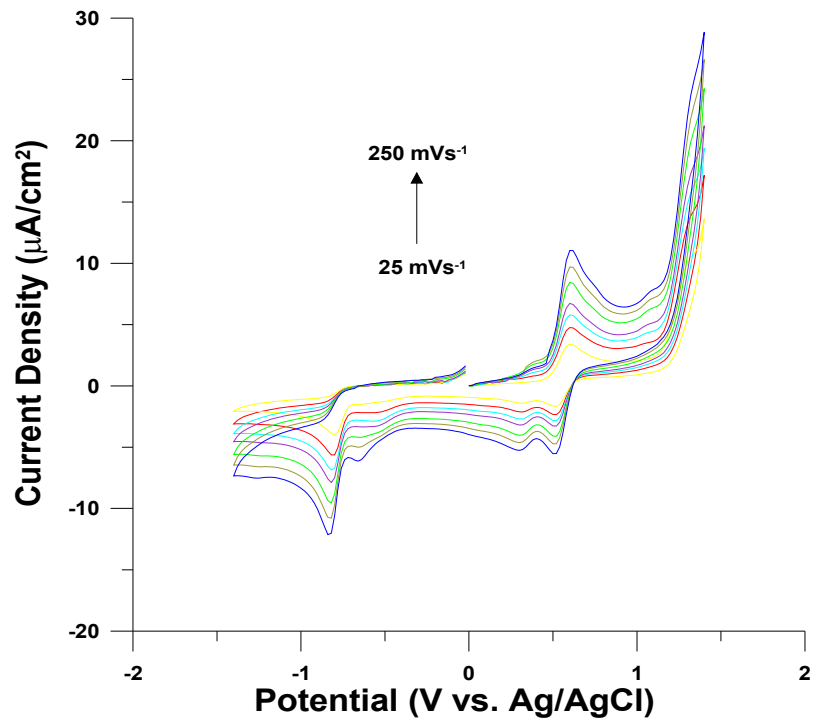

Figure 4: $\mathrm{CV}$ of the oxovanadium(IV) complex (2) in $0.1 \mathrm{M}$ TBAP/DMSO solution at $0.1 \mathrm{Vs}^{-1} \mathrm{scan}^{\mathrm{rate}}$ (left) and other different scan rates (right).

Table 4: Electrochemical parameters of $1.0 \times 10^{-3} \mathrm{M}$ oxovanadium(IV) complex (2) in DMSO/TBAP at 0.1 $\mathrm{Vs}^{-1}$ scan rate.

Peak Parameters

\begin{tabular}{llccc}
\hline Complex & Redox Process & ${ }^{\mathrm{a}} \mathbf{E}_{\mathbf{1 / 2}} \mathbf{( V )}$ & ${ }^{\mathbf{b}_{\mathbf{p}} / \boldsymbol{i}_{\mathbf{p c}}}$ & ${ }^{\mathrm{c}} \boldsymbol{\Delta} \mathbf{E}_{\mathrm{p}}(\mathbf{m V} \mathbf{)}$ \\
\hline $\mathbf{2}$ & $\mathrm{V}^{\mathrm{IV} / \mathrm{N}} \mathrm{O}$ & 0.56 & 1.1 & 80 \\
& $\mathrm{~V}^{\mathrm{IV} / \mathrm{III}} \mathrm{O}$ & -0.77 & 0.2 & 100 \\
\hline
\end{tabular}

${ }^{a} E_{1 / 2}=\left(E_{p a}+E_{p c}\right) / 2 \quad E_{p a}$ and $E_{p c}$ are the cathodic and anodic peak potentials, respectively.

$\mathrm{b}_{\mathrm{pa}}$ and $\mathrm{i}_{\mathrm{pc}}$ are the anodic and cathodic peak currents, respectively.

${ }^{\mathrm{c}} \Delta \mathrm{E}_{\mathrm{p}}$ is peak-to-peak separation $\left(\Delta \mathrm{E}_{\mathrm{p}}=\left|\mathrm{E}_{\mathrm{pa}}-\mathrm{E}_{\mathrm{pc}}\right|\right)$.

\section{Thermogravimetric data}

Table 5, Figure 5, and Figure S1-S2 present the TGA and DTG results for the starting compound (1) and the vanadium complex (2) in detail. The starting compound (1) underwent degradation in two steps, and sulfur (S) remained intact. First, allyl group $\left(-\mathrm{CH}_{2}-\mathrm{CH}=\mathrm{CH}_{2}\right)$ left, then $2-\mathrm{OH}-\left(\mathrm{C}_{6} \mathrm{H}_{5}\right)_{2}-$ $\mathrm{C}=\mathrm{N}-\mathrm{N}=\mathrm{C}-\mathrm{NH}_{2}$ degraded. 
The vanadium complex (2) underwent degradation in two steps, and $\mathrm{VO}+\mathrm{S}$ remained intact. First, $\mathrm{CH}_{2}-\mathrm{CH}=\mathrm{CH}_{2}+\mathrm{O}-\mathrm{CH}_{3}$ and coordinated water left the compound, then 2-OH- $\left(\mathrm{C}_{6} \mathrm{H}_{5}\right)_{2}-\mathrm{C}=\mathrm{N}-\mathrm{N}=\mathrm{C}-\mathrm{N}=\mathrm{C}-$ $\left(\mathrm{C}_{6} \mathrm{H}_{5}\right)$ degraded. Both structures are stable at room temperature, and they degrade at high temperatures $(38,47)$. Thermogravimetric analysis shows that the oxovanadium(IV) complex (2) is stable even in high temperatures.

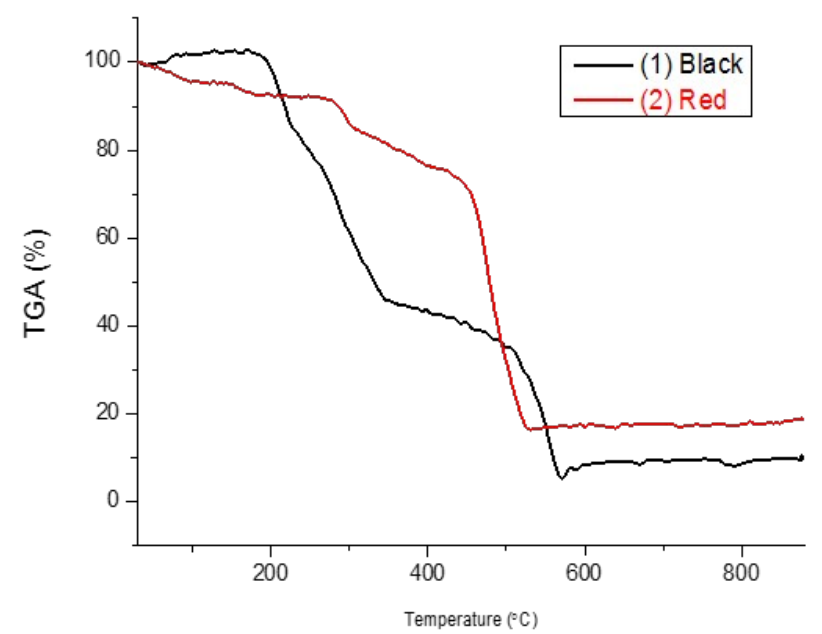

Figure 5: TGA-DTGA curves of S-allyl thiosemicarbazone (black, 1) and oxovanadium(IV) complex (red, 2).

Table 5: Thermogravimetric data for compound $\mathbf{1}$ and 2.

\begin{tabular}{|c|c|c|c|c|c|}
\hline Compound & Step & $\begin{array}{c}\text { Temperature } \\
\text { Range }\left({ }^{\circ} \mathbf{C}\right)\end{array}$ & $\begin{array}{c}\text { DTG } \\
\left({ }^{\circ} \mathbf{C}\right)\end{array}$ & $\begin{array}{c}\text { Weight loss } \\
(\mathbf{\%}) \\
\text { Found } \\
\text { (Calcd.) }\end{array}$ & Residue \\
\hline $\mathbf{1}$ & 1 st & $153-223$ & 171 & $13.07(13.18)$ & \\
\hline $\mathbf{2}$ & 2nd & $460-581$ & 553 & $76.74(76.84)$ & $10.19(10.27)$ \\
\hline & 1st & $240-321$ & 279 & $17.13(17.05)$ & \\
\hline & 2nd & $402-531$ & 501 & $64.15(64.21)$ & $18.79(18.72)$ \\
\hline
\end{tabular}

\section{Electronic spectra}

Ultraviolet-visible spectra were obtained between 200-900 nm in a chloroform solution. At $260 \mathrm{~nm}$, there was the starting material's (1) $\pi-\pi^{*}$ transition. For the oxovanadium complex, this transition was spotted at $266 \mathrm{~nm}$. This is caused by the presence of the benzophenone ring system.
The azomethine- and thioamide-originated $n-\pi^{*}$ transitions were observed at 306 and $340 \mathrm{~nm}$, while in compound $\mathbf{2}$, these transitions were observed at 338 and $361 \mathrm{~nm}$. In addition, the vanadium complex featured a ligand-to-metal transition (LMCT) at $440 \mathrm{~nm}$ in the Figure 6. These transitions support the square pyramidal structure $(42,48)$.

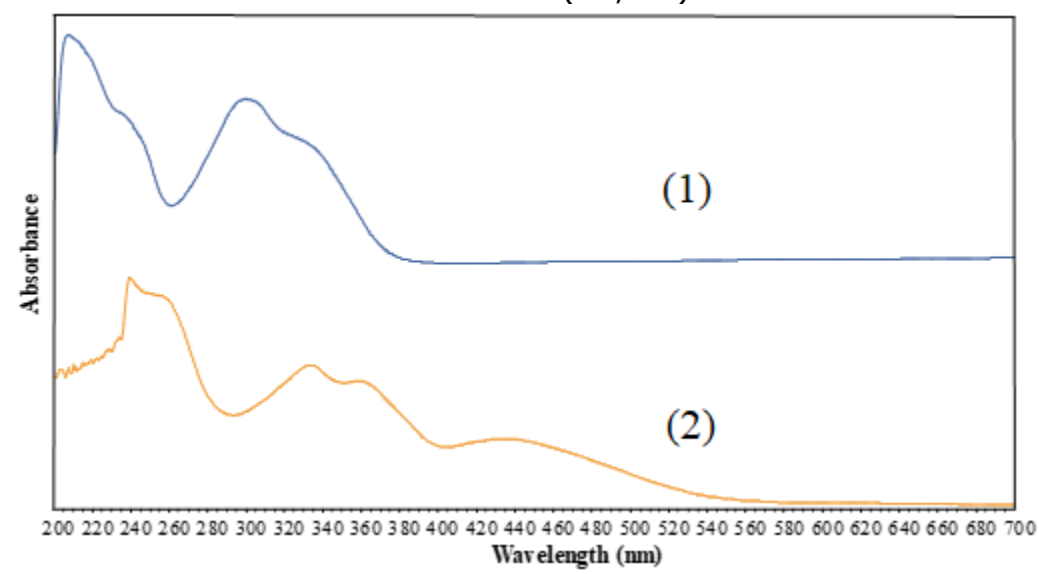

Figure 6: UV spectra of S-allyl-thiosemicarbazone (1), oxovanadium(IV) complex (2). 


\section{Infrared spectra}

The $\mathrm{v}(\mathrm{OH})$ stretching vibration for compound (1) was observed at $3468 \mathrm{~cm}^{-1}$. Asymmetric $\mathrm{NH}_{2}$ vibration, symmetric $\mathrm{NH}_{2}$ vibration, and $\mathrm{NH}_{2}$ deformation peaks were seen at 3329, 3284, and $1630 \mathrm{~cm}^{-1}$, respectively. Azomethine $\left(\mathrm{C}=\mathrm{N}^{1}\right)$ and $\left(\mathrm{C}=\mathrm{N}^{2}\right)$ vibrations were observed at 1600 and 1561 $\mathrm{cm}^{-1}$, respectively. At the end of template reaction, the $\mathrm{OH}$, asymmetric $\mathrm{NH}_{2}$, and symmetric $\mathrm{NH}_{2}$ vibrations disappeared, as expected. In addition,
$\mathrm{v}\left(\mathrm{N}^{4}=\mathrm{C}\right)$ was observed at $1519 \mathrm{~cm}^{-1}$ as a new band, which confirmed the template synthesis. $\mathrm{v}(\mathrm{V}=\mathrm{O})$ band was seen at $966 \mathrm{~cm}^{-1}$. This could be used as an indicator of template complexation. Disappearance or appearance of the aforementioned peaks serve as a confirming entity of the template reaction and thus, the template complex (2) in the Figure $7(14,38)$. The infrared spectrum of compound (1) is available in the supplementary material (Fig. S3).

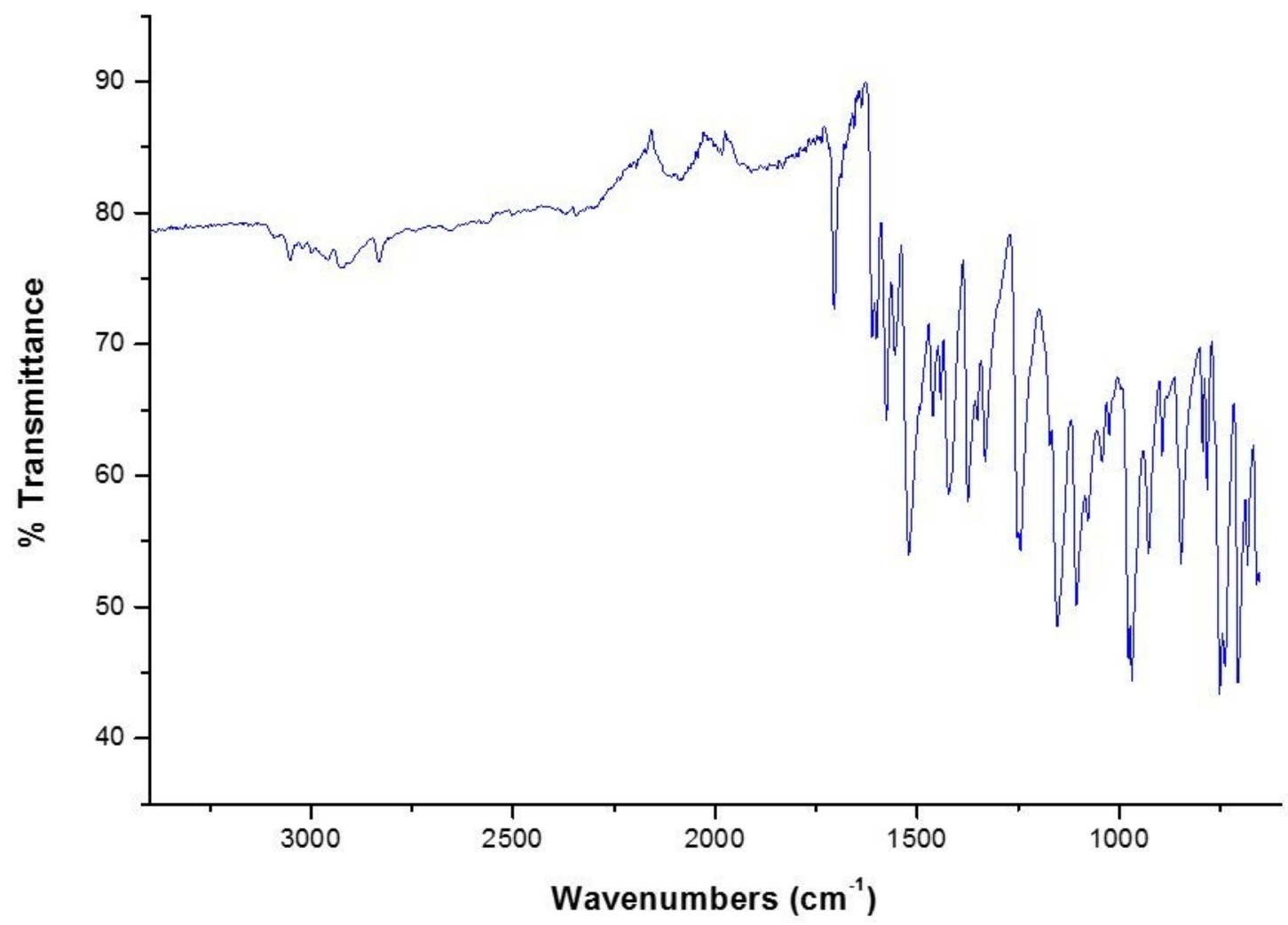

Figure 7: FT-IR spectrum of the oxovanadium(IV) complex (2).

\section{Mass Spectrometry}

The electron spray ionization (ESI) mass spectrum of compound $\mathbf{2}$ showed the molecular ion peak at $\mathrm{m} / \mathrm{z}$ 528.47, featuring a molecular formula of $\mathrm{C}_{25} \mathrm{H}_{25} \mathrm{~N}_{3} \mathrm{O}_{5} \mathrm{SV}$. In the spectrum, the molecular ion peak relative ratio was 22.91 for $533.1\left[\left(\mathrm{M}-\mathrm{H}_{2} \mathrm{O}\right)+\right.$ $\mathrm{Na}$ ]. The $\left(\mathrm{M}-\mathrm{H}_{2} \mathrm{O}\right)$ peak's ratio was 9.46 and the position was at $511.1\left[\left(2 \mathrm{M}-2 \mathrm{H}_{2} \mathrm{O}\right)+\mathrm{Na}\right]$ peak supported the $\pi-\pi$ interaction in the molecule, with a relative ratio of $100 \%$ and relative $\mathrm{m} / \mathrm{z}$ of 1042.8. During the recording of the mass spectrum, coordinated water molecule left the complex (38). The detailed mass spectrum is available in the supplementary material (Fig. S4).

\section{Antioxidant efficiency}

The antioxidant efficiency was referenced against trolox, which is the water-soluble analog of Vitamin E. CUPRAC method was applied in this determination, and the results were reported as $\mu \mathrm{mol}$ trolox equivalent per gram of sample. In the determination, the redox chemistry of copper(II) to copper(I) in a neocuproine complex was assayed and reported. The trolox-equivalent antioxidant capacity (TEAC) value of the oxovanadium(IV) complex (TEAC CUPRAC $=3.10 \pm$ 0.01) was higher than the starting material, (1) (TEAC TUPRAC $=0.30 \pm 0.01$ ) and ascorbic acid (TEAC ascorbic acid $=1.00 \pm 0.01$ ). Therefore, the compound $\mathbf{2}$ could serve as a powerful antioxidant. Benzophenone thiosemicarbazone-based oxovanadium(IV) complexes have higher antioxidant activities than those containing naphthaldeyhde-based oxovanadium(IV) complexes $(14,38,49)$. 


\section{CONCLUSION}

2-Hydroxybenzophenone S-allylthiosemicarbazone (1) was reacted with vanadyl sulfate to obtain the template complex (2), and UV-Vis, FTIR, electrochemistry, and copper ion reducing antioxidant capacity measurements were conducted. The UV-Vis spectra showed $\pi-\pi^{*}$ and $n-$ $\pi^{*}$ transitions for the ligand and LMCT peak for the complex. FTIR was useful to point to the vibrations present before complexation, and they disappeared after the formation of the template structure. Similarly, new bands were obtained after template complex formation. Thermogravimetric analysis of compounds $\mathbf{1}$ and $\mathbf{2}$ revealed that they were stable at high temperatures. Mass spectra showed that the $\pi-\pi$ and $C-\pi$ interactions were present in the complex.

Electrochemistry of the complex, supplied valuable information for the redox chemistry of vanadiumcentered template; an oxidation couple from $\mathrm{V}^{\mathrm{IV}}$ to $\mathrm{V}^{\mathrm{V}}$ were clearly identified. A further reduction from $\mathrm{V}^{\mathrm{IV}}$ to $\mathrm{V}^{\mathrm{III}}$ was also recorded. Oxidation of the ligand was not observed.

Copper ion reducing antioxidant capacity experiment showed that the complex $\mathbf{2}$ is a potent antioxidant and its trolox-equivalent antioxidant capacity is at least three times more powerful than ascorbic acid. A less positive oxidation potential is a requirement for a powerful reducing agent, as shown by electrochemical measurements. Oxovanadium(IV) complex (2) has this requirement and it is a better reducing agent. CUPRAC results are confirmed by a high ligandbased reduction potential and complex $\mathbf{2}$ is suitable as an antioxidant agent (14).

\section{ACKNOWLEDGEMENTS}

This manuscript is dedicated to Dr. Bahri ÜLKÜSEVEN and Dr. Yasemin KURT as being my prime directors of my career.

Supplementary crystallographic data are deposited with the CCDC number of 2075485 for compound (2) $\left(\mathrm{C}_{25} \mathrm{H}_{25} \mathrm{~N}_{3} \mathrm{O}_{5} \mathrm{SV}\right)$. It is free of charge to obtain the data from Cambridge Crystallographic Data Center http://www.ccdc.cam.ac.ac.uk/conts/retrieving.ht $\mathrm{ml}$ website or from the postal address of Cambridge Crystallographic Data Center, 12, Union Road, Cambridge CB2 1EZ, UK; fax: +44 1223336 033 or from the e-mail deposit@ccdc.cam.ac.uk.

The Research Fund of Istanbul UniversityCerrahpasa supported this work, with Project numbers 24195 and 34846.

\section{REFERENCES}

1. Mendes IC, Botion LM, Ferreira AVM, Castellano $\mathrm{EE}$, Beraldo $\mathrm{H}$. Vanadium complexes with 2pyridineformamide thiosemicarbazones: In vitro studies of insulin-like activity. Inorganica Chimica Acta. 2009 Jan;362(2):414-20.

2. Far BS, Grivani G, Khalaji AD, Khorshidi M, Gholizadeh A. A new six coordinated oxidovanadium(IV) Schiff base complex: Synthesis, characterization, crystal structure, thermal study and antibacterial activity. Journal of Molecular Structure. 2019 Dec;1197:361-8.

3. Bhattacharjee CR, Goswami $P$, Sengupta $M$. Synthesis, electrochemical and antimicrobial studies of mono and binuclear iron(III) and oxovanadium(IV) complexes of [ONO] donor tridentate Schiff-base ligands. Journal of Coordination Chemistry. $2010 \quad$ Nov 20;63(22):3969-80.

4. Akhter S, Zaman HU, Mir S, Dar AM, Shrivastava S. SYNTHESIS OF SCHIFF BASE METAL COMPLEXES: A CONCISE REVIEW. ECB. 2017 Dec 19;6(10):475.

5. Meng X-F, Liu Q-F, Liu J-L, Sun M-H, Ma J-J. Synthesis, crystal structure, and insulin-like activity of [ $N^{\prime}$-(2-hydroxy-3methoxybenzylidene)-2-

methoxybenzohydrazonato] $(1,10$ -

phenanthroline)oxovanadium(IV)

methanol solvate. Inorganic and Nano-Metal Chemistry. 2017 Nov 2;47(11):1585-9.

6. Saatchi $K$, Thompson $\mathrm{KH}$, Patrick BO, Pink $\mathrm{M}$, Yuen VG, McNeill JH, et al. Coordination Chemistry and Insulin-Enhancing Behavior of Vanadium Complexes with Maltol $\mathrm{C}_{6} \mathrm{H}_{6} \mathrm{O}_{3}$ Structural Isomers. Inorg Chem. 2005 Apr;44(8):2689-97.

7. Storr $T$, Mitchell $D$, Buglyó $P$, Thompson $\mathrm{KH}$, Yuen VG, McNeill JH, et al. Vanadyl-Thiazolidinedione Combination Agents for Diabetes Therapy. Bioconjugate Chem. 2003 Jan; 14(1):212-21.

8. Bharathi $S$, Mahendiran $D$, Senthil Kumar R, Kalilur Rahiman A. In Vitro Antioxidant and Insulin Mimetic Activities of Heteroleptic Oxovanadium(IV) Complexes with Thiosemicarbazones and Naproxen. ChemistrySelect. 2020 Jun $8 ; 5(21): 6245-54$.

9. Tunali $S$, Gezginci-Oktayoglu S, Bolkent $S$, Coskun E, Bal-Demirci T, Ulkuseven B, et al. Protective Effects of an Oxovanadium(IV) Complex with $\mathrm{N}_{2} \mathrm{O}_{2}$ Chelating Thiosemicarbazone on Small 
Intestine Injury of STZ-Diabetic Rats. Biol Trace Elem Res. 2021 Apr;199(4):1515-23.

10. Kanchanadevi A, Ramesh R, Semeril D. Synthesis of $\mathrm{Ru}(\mathrm{II})$ pyridoxal thiosemicarbazone complex and its catalytic application to one-pot conversion of aldehydes to primary amides. Inorganic Chemistry Communications. 2015 Jun;56:116-9.

11. Paul $P$, Sengupta $P$, Bhattacharya S. Palladium mediated $\mathrm{C}-\mathrm{H}$ bond activation of thiosemicarbazones: Catalytic application of organopalladium complexes in $\mathrm{C}-\mathrm{C}$ and $\mathrm{C}-\mathrm{N}$ coupling reactions. Journal of Organometallic Chemistry. 2013 Jan;724:281-8.

12. Prabhu RN, Ramesh R. Synthesis and structural characterization of palladium(II) thiosemicarbazone complex: application to the Buchwald-Hartwig amination reaction. Tetrahedron Letters. 2013 Feb;54(9):1120-4.

13. Quiroga-Campano C, Gómez-Machuca $H$, Moris S, Pessoa-Mahana H, Jullian C, Saitz C. Synthesis of calix[4]arenes bearing thiosemicarbazone moieties with naphthalene groups: Highly selective turn off/on fluorescent sensor for $\mathrm{Cu}$ (II) recognition. Journal of Molecular Structure. 2021 Feb;1225:129125.

14. İlhan Ceylan B, Yilmaz A, Bölükbaşı O, Acar ET, Özyürek $M$, Kurt $Y$, et al. A square-pyramidal iron(III) complex obtained from 2-hydroxybenzophenone- $S$-allyl-thiosemicarbazone: synthesis, characterization, electrochemistry, quantum chemical studies and antioxidant capability. Journal of Coordination Chemistry. 2020 Jan $2 ; 73(1): 120-36$.

15. Poladian Q, Şahin O, Karakurt T, İlhan-Ceylan $B$, Kurt Y. A new zinc(II) complex with N2O2tetradentate schiff-base derived from pyridoxal-Smethylthiosemicarbazone: Synthesis, characterization, crystal structure, DFT, molecular docking and antioxidant activity studies. Polyhedron. 2021 Jun;201:115164.

16. Jia X, Liu Q, Wang S, Zeng B, Du G, Zhang C, et al. Synthesis, cytotoxicity, and in vivo antitumor activity study of parthenolide semicarbazones and thiosemicarbazones. Bioorganic \& Medicinal Chemistry. 2020 Jul;28(13):115557.

17. Aly MM, Mohamed YA, El-Bayouki KAM, Basyouni WM, Abbas SY. Synthesis of some new 4(3H)-quinazolinone-2-carboxaldehyde thiosemicarbazones and their metal complexes and a study on their anticonvulsant, analgesic, cytotoxic and antimicrobial activities - Part- 1 .
European Journal of Medicinal Chemistry. 2010 Aug;45(8):3365-73.

18. Yanardag R, Demirci TB, Ülküseven B, Bolkent S, Tunali S, Bolkent S. Synthesis, characterization and antidiabetic properties of N1-2,4dihydroxybenzylidene-N4-2-hydroxybenzylidene-Smethyl-thiosemicarbazidato-oxovanadium(IV).

European Journal of Medicinal Chemistry. 2009 Feb;44(2):818-26.

19. Biot C, Castro W, Botté CY, Navarro M. The therapeutic potential of metal-based antimalarial agents: Implications for the mechanism of action. Dalton Trans. 2012;41(21):6335.

20. Genova $\mathrm{P}$, Varadinova $\mathrm{T}$, Matesanz AI, Marinova D, Souza P. Toxic effects of bis(thiosemicarbazone) compounds and its palladium(II) complexes on herpes simplex virus growth. Toxicology and Applied Pharmacology. 2004 Jun; 197(2): 107-12.

21. Fonteh PN, Keter FK, Meyer D. New bis(thiosemicarbazonate) gold(III) complexes inhibit HIV replication at cytostatic concentrations: Potential for incorporation into virostatic cocktails. Journal of Inorganic Biochemistry. 2011 Sep;105(9):1173-80.

22. Yildirim H, Guler E, Yavuz M, Ozturk N, Kose Yaman $P$, Subasi $E$, et al. Ruthenium (II) complexes of thiosemicarbazone: Synthesis, biosensor applications and evaluation as antimicrobial agents. Materials Science and Engineering: C. 2014 Nov;44:1-8.

23. de Araújo Neto $L N$, de Lima $M$ do $C A$, de Oliveira JF, de Souza ER, Feitosa Machado SE, de Souza Lima GM, et al. Thiophenethiosemicarbazone derivative (L10) exerts antifungal activity mediated by oxidative stress and apoptosis in C. albicans. Chemico-Biological Interactions. 2020 Apr;320:109028.

24. de Araújo Neto LN, do Carmo Alves de Lima M, de Oliveira JF, de Souza ER, Buonafina MDS, Vitor Anjos MN, et al. Synthesis, cytotoxicity and antifungal activity of 5-nitro-thiophenethiosemicarbazones derivatives. Chemico-Biological Interactions. 2017 Jun;272:172-81.

25. Li J-Q, Sun L-Y, Jiang Z, Chen C, Gao H, Chigan J-Z, et al. Diaryl-substituted thiosemicarbazone: A potent scaffold for the development of New Delhi metallo- $\beta$-lactamase- 1 inhibitors. Bioorganic Chemistry. 2021 Feb;107:104576. 
26. Bisceglie F, Bacci C, Vismarra A, Barilli E, Pioli $M$, Orsoni $N$, et al. Antibacterial activity of metal complexes based on cinnamaldehyde thiosemicarbazone analogues. Journal of Inorganic Biochemistry. 2020 Feb;203:110888.

27. Singh NK, Kumbhar AA, Pokharel YR, Yadav PN. Anticancer potency of copper(II) complexes of thiosemicarbazones. Journal of Inorganic Biochemistry. 2020 Sep;210:111134.

28. Subasi E, Atalay EB, Erdogan D, Sen B, Pakyapan B, Kayali HA. Synthesis and characterization of thiosemicarbazonefunctionalized organoruthenium (II)-arene complexes: Investigation of antitumor characteristics in colorectal cancer cell lines. Materials Science and Engineering: C. 2020 Jan;106:110152.

29. de Oliveira JF, da Silva AL, Vendramini-Costa DB, da Cruz Amorim CA, Campos JF, Ribeiro AG, et al. Synthesis of thiophene-thiosemicarbazone derivatives and evaluation of their in vitro and in vivo antitumor activities. European Journal of Medicinal Chemistry. 2015 Nov;104:148-56.

30. Anonymous. Bruker, APEX2 \& SAINT. AXS Inc., Madison, WI; 2004.

31. Sheldrick G. Program for Crystal Structure Refinement. University of Göttingen, Germany; 2014.

32. Sheldrick GM. SHELXT - Integrated spacegroup and crystal-structure determination. Acta Crystallogr A Found Adv. 2015 Jan 1;71(1):3-8.

33. Yamazaki C. The Structure of Isothiosemicarbazones. Can J Chem. 1975 Feb $15 ; 53(4): 610-5$.

34. Apak R, Güçlü K, Özyürek M, Karademir SE. Novel Total Antioxidant Capacity Index for Dietary Polyphenols and Vitamins C and E, Using Their Cupric Ion Reducing Capability in the Presence of Neocuproine: CUPRAC Method. J Agric Food Chem. 2004 Dec;52(26):7970-81.

35. Dekar S, Ouari K, Bendia S, Hannachi D, Weiss J. Mononuclear oxovanadium(IV) Schiff base complex: Synthesis, spectroscopy, electrochemistry, DFT calculation and catalytic activity. Journal of Organometallic Chemistry. 2018 Jul;866:165-76.

36. Jeyaraman P, Alagarraj A, Natarajan R. In silico and in vitro studies of transition metal complexes derived from curcumin-isoniazid Schiff base. Journal of Biomolecular Structure and Dynamics. 2020 Jan 22;38(2):488-99.

37. Abu-Dief AM, Nassr LAE. Tailoring, physicochemical characterization, antibacterial and DNA binding mode studies of $\mathrm{Cu}$ (II) Schiff bases amino acid bioactive agents incorporating 5bromo-2-hydroxybenzaldehyde. J IRAN CHEM SOC. 2015 Jun;12(6):943-55.

38. İlhan-Ceylan B. Oxovanadium(IV) and Nickel(II) complexes obtained from 2,2'dihydroxybenzophenone-S-methyl-

thiosemicarbazone: Synthesis, characterization, electrochemistry, and antioxidant capability. Inorganica Chimica Acta. 2021 Mar;517:120186.

39. Ilhan Ceylan B. Oxovanadıum(IV)-containing $\mathrm{N}_{2} \mathrm{O}_{2}$ chelate complex; crystal structure determination and DFT. J Turk Chem Soc, Sect A: Chem [Internet]. 2016 Sep 30 [cited 2021 Apr 7];3(3). Available from: http://dergipark.gov.tr/doi/10.18596/jotcsa.33245

40. Ze-hua L, Chun-ying D, Ji-hui L, Yong-jiang L, Yu-hua M, Xiao-zeng Y. Structural dependence of $\pi-\pi$ interactions in dithiocarbazato and thiosemicarbazato nickel complexes. New J Chem. $2000 ; 24(12): 1057-62$.

41. Addison AW, Rao TN, Reedijk J, van Rijn J, Verschoor GC. Synthesis, structure, and spectroscopic properties of copper( II ) compounds containing nitrogen-sulphur donor ligands; the crystal and molecular structure of aqua[1,7-bis(Nmethylbenzimidazol-2'-yl)-2,6-

dithiaheptane]copper( II ) perchlorate. J Chem Soc, Dalton Trans. 1984;(7):1349-56.

42. Menati S, Rudbari HA, Khorshidifard M, Jalilian F. A new oxovanadium(IV) complex containing an $\mathrm{O}, \mathrm{N}$-bidentate Schiff base ligand: Synthesis at ambient temperature, characterization, crystal structure and catalytic performance in selective oxidation of sulfides to sulfones using $\mathrm{H}_{2} \mathrm{O}_{2}$ under solvent-free conditions. Journal of Molecular Structure. 2016 Jan;1103:94-102.

43. Dekar S, Ouari K, Bendia S, Hannachi D, Weiss J. Mononuclear oxovanadium(IV) Schiff base complex: Synthesis, spectroscopy, electrochemistry, DFT calculation and catalytic activity. Journal of Organometallic Chemistry. 2018 Jul;866:165-76.

44. Kurt $Y$, İlhan-Ceylan $B$, Açıkgöz $M$, Tüzün $E$, Atun $\mathrm{G}$, Ülküseven $\mathrm{B}$. $\mathrm{N}_{2} \mathrm{O}_{2}$-complexes of oxovanadium(IV) with 2,2'dihydroxybenzophenone thiosemicarbazones: Synthesis, EPR and electrochemical studies. Polyhedron. 2013 Nov;65:67-72. 
45. Kurt $Y$, Koca $A$, Akkurt $M$, Ülküseven $B$. Iron(III) and nickel(II) complexes of $\mathrm{O}, \mathrm{N}, \mathrm{N}, \mathrm{O}-$ chelating benzophenone thiosemicarbazone: Electrochemistry and in situ spectroelectrochemistry. Inorganica Chimica Acta. 2012 Jun;388: 148-56.

46. Aranha PE, Souza JM, Romera S, Ramos LA, dos Santos MP, Dockal ER, et al. Thermal behavior of vanadyl complexes with Schiff bases derived from trans- $\mathrm{N}, \mathrm{N}^{\prime}$-bis(salicylidene)-1,2cyclohexadiamine (t-Salcn). Thermochimica Acta. 2007 Jan;453(1):9-13.

47. Asadi M, Asadi Z, Savaripoor N, Dusek $M$, Eigner $V$, Shorkaei MR, et al. Structural investigation of oxovanadium(IV) Schiff base complexes: X-ray crystallography, electrochemistry and kinetic of thermal decomposition. Spectrochimica Acta Part A: Molecular and Biomolecular Spectroscopy. 2015 Feb;136:625-34.

48. Maurya MR, Kumar A, Abid M, Azam A. Dioxovanadium(V) and $\mu$-oxo bis[oxovanadium(V)] complexes containing thiosemicarbazone based ONS donor set and their antiamoebic activity. Inorganica Chimica Acta. 2006 May;359(8):243947.

49. Ilhan-Ceylan B, Tuzun E, Kurt Y, Acikgoz M, Kahraman S, Atun G, Ulkuseven B, "Oxovanadium(IV) complexes based on S-alkylthiosemicarbazidato ligands. Synthesis, characterization, electrochemical, and antioxidant studies", Journal of Sulfur Chemistry. 2015; 36: 434-449. 
Oxovanadium(IV) template derived from benzophenone S-allyl thiosemicarbazone: Synthesis, crystal structure, antioxidant activity and electrochemistry

\author{
Berat İlhan-Ceylan \\ Istanbul University-Cerrahpasa, Engineering Faculty, Department of Chemistry, Inorganic Chemistry \\ Division, 34320, Avcllar, Istanbul, Turkey
}

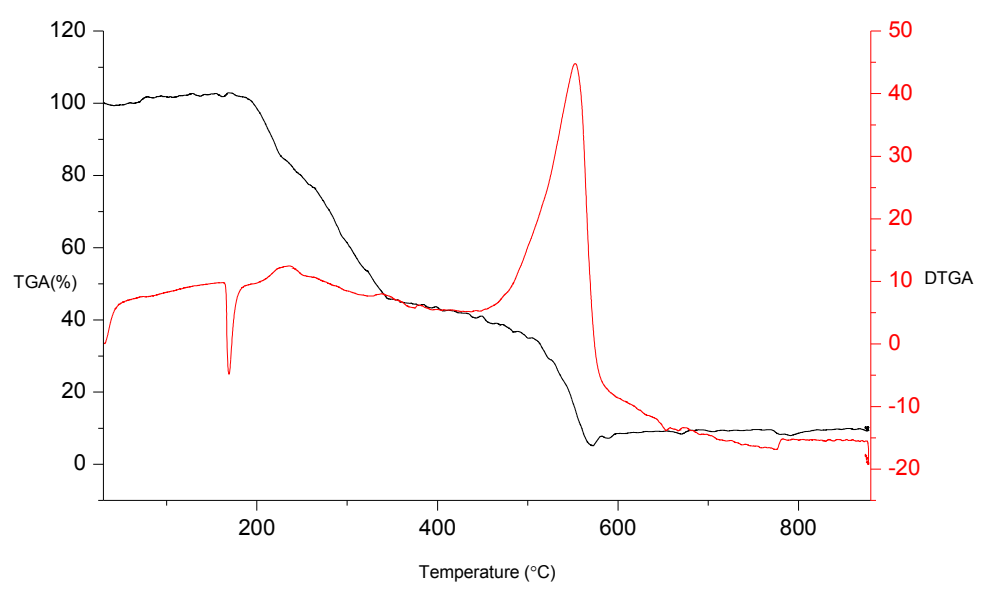

Figure S1: TGA-DTGA curves of S-allyl-thiosemicarbazone (1).

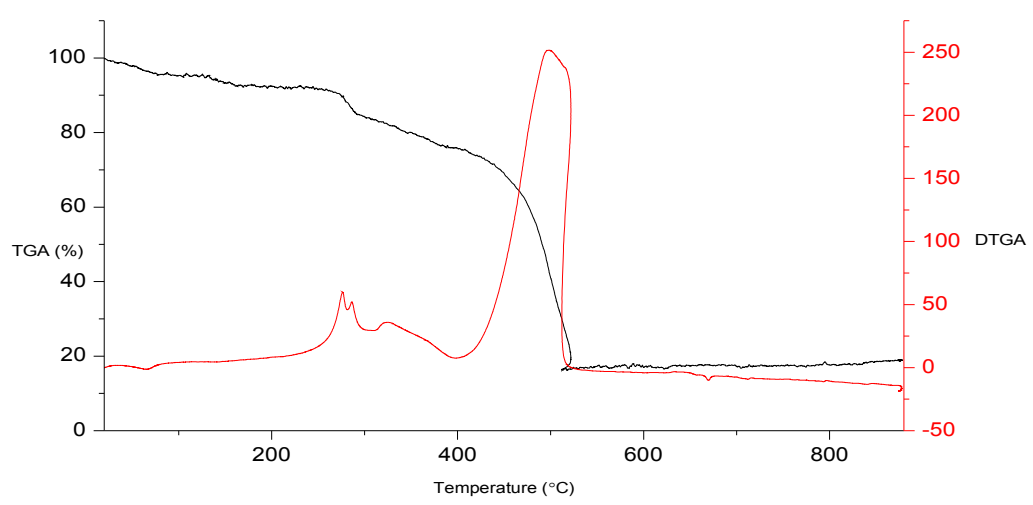

Figure S2: TGA-DTGA curves of oxovanadium(IV) complex (2). 


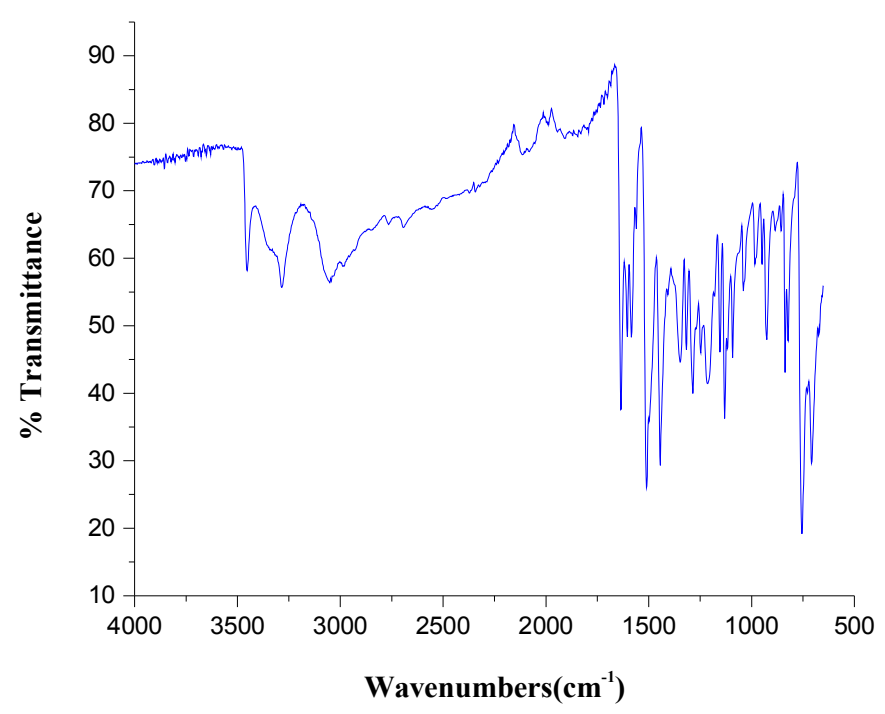

Figure S3: FT-IR spectra of S-allyl-thiosemicarbazone (1).

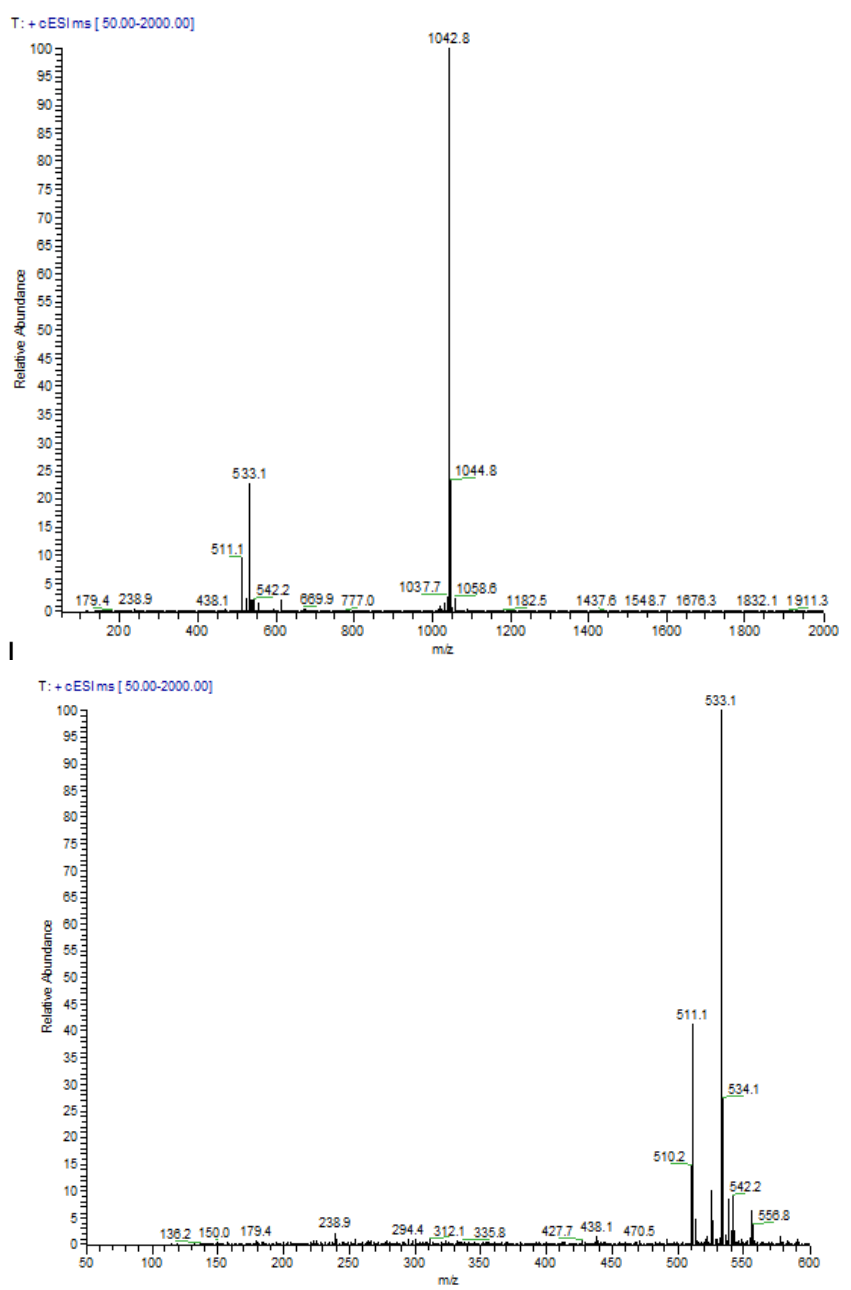

Figure S4: Mass spectra of the oxovanadium(IV) complex (2). 
Table S1: Anisotropic displacement parameters $\left(\AA^{2} \times 10^{3}\right)$ for the oxovanadium (IV) complex. The anisotropic displacement factor exponent takes the form: $-2 \pi^{2}\left[h^{2} a * 2 u^{11}+\ldots+2 h k a * b * u^{12}\right]$

\begin{tabular}{|c|c|c|c|c|c|c|}
\hline & $u^{11}$ & $u^{22}$ & $u^{33}$ & $u^{23}$ & $u^{13}$ & $u^{12}$ \\
\hline $\mathrm{V}(1)$ & $32(1)$ & $51(1)$ & $47(1)$ & $18(1)$ & $2(1)$ & $13(1)$ \\
\hline $\mathrm{S}(1)$ & $56(1)$ & $88(1)$ & $53(1)$ & $35(1)$ & $10(1)$ & $20(1)$ \\
\hline $\mathrm{O}(1)$ & $45(2)$ & $94(3)$ & $59(3)$ & $35(2)$ & $1(2)$ & $21(2)$ \\
\hline $\mathrm{O}(2)$ & $36(2)$ & $70(2)$ & $50(2)$ & $28(2)$ & $7(2)$ & $17(2)$ \\
\hline $\mathrm{O}(3)$ & $38(2)$ & $61(2)$ & $64(3)$ & $32(2)$ & $6(2)$ & $15(2)$ \\
\hline $\mathrm{O}(4)$ & $45(2)$ & $55(2)$ & $60(2)$ & $12(2)$ & $6(2)$ & $17(2)$ \\
\hline$N(2)$ & $36(2)$ & $54(3)$ & $49(3)$ & $18(2)$ & $3(2)$ & $11(2)$ \\
\hline$N(3)$ & $39(2)$ & $44(2)$ & $46(3)$ & $17(2)$ & $-2(2)$ & $11(2)$ \\
\hline$N(4)$ & $35(2)$ & $48(3)$ & $46(3)$ & $16(2)$ & $5(2)$ & $9(2)$ \\
\hline$C(1)$ & $34(3)$ & $44(3)$ & $54(3)$ & $10(3)$ & $3(2)$ & $11(2)$ \\
\hline$C(2)$ & $37(3)$ & $53(3)$ & $54(3)$ & $18(3)$ & $7(2)$ & $17(2)$ \\
\hline$C(3)$ & $36(3)$ & $60(3)$ & $66(4)$ & $24(3)$ & $0(3)$ & $15(3)$ \\
\hline$C(4)$ & $36(3)$ & $60(4)$ & $85(5)$ & $30(3)$ & $15(3)$ & $18(3)$ \\
\hline$C(5)$ & $45(3)$ & $58(3)$ & $66(4)$ & $31(3)$ & $17(3)$ & $21(3)$ \\
\hline$C(6)$ & $42(3)$ & $48(3)$ & $55(3)$ & $17(3)$ & $13(3)$ & $19(2)$ \\
\hline$C(7)$ & $59(4)$ & $116(6)$ & $68(4)$ & $41(4)$ & $-10(3)$ & $27(4)$ \\
\hline$C(8)$ & $45(3)$ & $48(3)$ & $46(3)$ & $21(2)$ & $10(2)$ & $15(2)$ \\
\hline$C(9)$ & $44(3)$ & $45(3)$ & $48(3)$ & $12(2)$ & $3(2)$ & $14(2)$ \\
\hline$C(10)$ & $35(3)$ & $40(3)$ & $51(3)$ & $12(2)$ & $5(2)$ & $10(2)$ \\
\hline$C(11)$ & $35(3)$ & $52(3)$ & $47(3)$ & $9(3)$ & $0(2)$ & $10(2)$ \\
\hline$C(12)$ & $36(3)$ & $98(5)$ & $53(4)$ & $24(3)$ & $2(3)$ & $18(3)$ \\
\hline$C(13)$ & $38(3)$ & $113(6)$ & $62(4)$ & $24(4)$ & $12(3)$ & $6(3)$ \\
\hline$C(14)$ & $50(3)$ & $74(4)$ & $62(4)$ & $26(3)$ & $15(3)$ & $11(3)$ \\
\hline$C(15)$ & $45(3)$ & $57(3)$ & $55(4)$ & $22(3)$ & $6(3)$ & $15(3)$ \\
\hline$C(16)$ & $37(3)$ & $38(3)$ & $51(3)$ & $9(2)$ & $2(2)$ & $12(2)$ \\
\hline$C(17)$ & $38(3)$ & $50(3)$ & $45(3)$ & $14(2)$ & $3(2)$ & $16(2)$ \\
\hline$C(18)$ & $41(3)$ & $54(3)$ & $53(3)$ & $17(3)$ & $2(3)$ & $8(3)$ \\
\hline$C(19)$ & $51(3)$ & $72(4)$ & $53(4)$ & $12(3)$ & $-2(3)$ & $7(3)$ \\
\hline$C(20)$ & $53(4)$ & $101(5)$ & $55(4)$ & $29(4)$ & $-2(3)$ & $34(4)$ \\
\hline$C(21)$ & $67(4)$ & $83(5)$ & $69(4)$ & $34(4)$ & $10(3)$ & $42(4)$ \\
\hline$C(22)$ & $51(3)$ & $56(3)$ & $63(4)$ & $22(3)$ & $8(3)$ & $19(3)$ \\
\hline$C(23)$ & $81(5)$ & $109(6)$ & $58(4)$ & $40(4)$ & $8(4)$ & $33(4)$ \\
\hline$C(24)$ & $1900(80)$ & $2030(80)$ & $430(40)$ & $-400(70)$ & $-400(70)$ & $1960(80)$ \\
\hline$C(25)$ & $880(60)$ & $360(20)$ & $80(9)$ & $79(13)$ & $-21(19)$ & $410(30)$ \\
\hline $\mathrm{O}(5)$ & $163(12)$ & $169(12)$ & $124(10)$ & $55(8)$ & $55(9)$ & $78(9)$ \\
\hline$O(5 A)$ & $111(11)$ & $147(12)$ & $83(9)$ & $8(8)$ & $33(8)$ & $81(10)$ \\
\hline
\end{tabular}

Table S2: Hydrogen coordinates ( $\left.\times 10^{4}\right)$ and isotropic displacement parameters $\left(\AA^{2} \times 10^{3}\right)$ for the oxovanadium (IV) complex.

\begin{tabular}{lrrrrlrrrr}
\hline & $\mathrm{x}$ & $\mathrm{y}$ & $\mathrm{z}$ & $\mathrm{U}(\mathrm{eq})$ & & $\mathrm{x}$ & $\mathrm{y}$ & $\mathrm{z}$ & $\mathrm{U}(\mathrm{eq})$ \\
\hline $\mathrm{H}(3)$ & 440 & 1192 & 1980 & 67 & $\mathrm{H}(20)$ & 15143 & 3873 & 9072 & 84 \\
$\mathrm{H}(4)$ & -141 & 464 & 3541 & 72 & $\mathrm{H}(21)$ & 13267 & 1921 & 8056 & 83 \\
$\mathrm{H}(5)$ & 1778 & 510 & 5002 & 65 & $\mathrm{H}(22)$ & 11175 & 1691 & 6579 & 70 \\
$\mathrm{H}(7 \mathrm{~A})$ & 2474 & 2435 & 94 & 129 & $\mathrm{H}(23 \mathrm{~A})$ & 8286 & 1110 & 8894 & 100 \\
$\mathrm{H}(7 \mathrm{~B})$ & 1418 & 2489 & 931 & 129 & $\mathrm{H}(23 \mathrm{~B})$ & 9212 & 2079 & 8319 & 100 \\
$\mathrm{H}(7 \mathrm{C})$ & 1314 & 1198 & 250 & 129 & $\mathrm{H}(24)$ & 8786 & 2524 & 10334 & 1584 \\
$\mathrm{H}(8)$ & 4430 & 1220 & 5983 & 57 & $\mathrm{H}(25 \mathrm{~A})$ & 9519 & 3652 & 8618 & 626 \\
$\mathrm{H}(12)$ & 13339 & 4184 & 5204 & 79 & $\mathrm{H}(25 \mathrm{~B})$ & 10880 & 3869 & 9693 & 626 \\
$\mathrm{H}(13)$ & 14149 & 5014 & 3779 & 95 & $\mathrm{H}(25 \mathrm{C})$ & 9621 & 4383 & 9869 & 626 \\
$\mathrm{H}(14)$ & 12397 & 5241 & 2341 & 78 & $\mathrm{H}(5 \mathrm{~A})$ & 5313 & 1723 & 1094 & 217 \\
$\mathrm{H}(15)$ & 9812 & 4453 & 2242 & 65 & $\mathrm{H}(5 \mathrm{~B})$ & 6371 & 1605 & 488 & 217 \\
$\mathrm{H}(18)$ & 12929 & 5400 & 7095 & 65 & $\mathrm{H}(5 \mathrm{AA})$ & 6626 & 121 & 1356 & 162 \\
$\mathrm{H}(19)$ & 14924 & 5609 & 8654 & 81 & $\mathrm{H}(5 \mathrm{BB})$ & 7215 & 1048 & 872 & 162 \\
\hline
\end{tabular}


İlhan-Ceylan B. JOTCSA. 2021; 8(2): 593-608.

RESEARCH ARTICLE 